University of South Florida

DIGITAL COMMONS

Digital Commons @ University of

@ UNIVERSITY OF SOUTH FLORIDA

South Florida

Marine Science Faculty Publications

College of Marine Science

2-15-2001

\title{
ENSO Influences on Seasonal Rainfall and River Discharge in Florida
}

Nancy Schmidt

University of South Florida

E. K. Lipp

University of Maryland Biotechnology Institute

J. B. Rose

University of South Florida

Mark E. Luther

University of South Florida, mluther@usf.edu

Follow this and additional works at: https://digitalcommons.usf.edu/msc_facpub

Part of the Life Sciences Commons

\section{Scholar Commons Citation}

Schmidt, Nancy; Lipp, E. K.; Rose, J. B.; and Luther, Mark E., "ENSO Influences on Seasonal Rainfall and River Discharge in Florida" (2001). Marine Science Faculty Publications. 512.

https://digitalcommons.usf.edu/msc_facpub/512

This Article is brought to you for free and open access by the College of Marine Science at Digital Commons @ University of South Florida. It has been accepted for inclusion in Marine Science Faculty Publications by an authorized administrator of Digital Commons @ University of South Florida. For more information, please contact digitalcommons@usf.edu. 


\title{
NOTES AND CORRESPONDENCE
}

\section{ENSO Influences on Seasonal Rainfall and River Discharge in Florida}

\author{
NANCY SCHMIDT \\ College of Marine Science, University of South Florida, St. Petersburg, Florida \\ E. K. LIPP \\ University of Maryland Biotechnology Institute, Center of Marine Biotechnology, \\ Baltimore, Maryland \\ J. B. Rose And M. E. Luther \\ College of Marine Science, University of South Florida, St. Petersburg, Florida
}

8 September 1999 and 3 July 2000

\section{ABSTRACT}

\begin{abstract}
Hemispherical and regional analyses of climatic patterns relating to El Niño-Southern Oscillation (ENSO) indicate strong responses in the southeastern United States, especially during the wintertime. Using Florida as an example, the authors focused on local-scale patterns within this region in order to examine the geographic variability of seasonal rainfall and river discharge as related to ENSO. Forty-eight years (1950-98) of precipitation and river discharge data in Florida were classified, using sea surface temperature anomaly data from the equatorial Pacific Ocean, as occurring during an El Niño (warm event), La Niña (cold event), or neither (neutral). Seasonal precipitation and streamflow both exhibited strong responses to ENSO as shown by their relationships to Niño3.4 sea surface temperature anomalies. Florida does not respond as a uniform region to ENSO, particularly with respect to precipitation in the Panhandle and the southernmost areas of Florida. In particular, seasonal river discharge in south-central Florida responds in a complicated manner to ENSO conditions; however, there are seasonal ENSO patterns. The authors have linked the results of larger regional and hemispherical research to a focused local-scale approach that demonstrates variability in precipitation and river flow using datasets and statistical techniques that are readily available to and interpretable by water resource planners and managers.
\end{abstract}

\section{Introduction}

The relationship of the El Niño-Southern Oscillation (ENSO) phenomena to global climate patterns is a topic of considerable interest and importance because of its documented effect on so many natural and social disasters-drought, flood, famine, hurricanes, disease, to mention just a few. For example, Epstein (1998) cites costs of over $\$ 1$ billion for the 1991 ENSO-related cholera epidemic in Peru, mostly from losses in seafood export and tourist income, and, the National Center for Atmospheric Research (1994) reports that the U.S. Gulf of Mexico region experienced over $\$ 1.27$ billion in losses associated with flooding during the 1982-83 El Niño (warm) event. Checkley et al. (2000) document a 200\% increase in the number of children diagnosed with non-

Corresponding author address: Nancy Schmidt, College of Marine Science, University of South Florida, 140 Seventh Avenue South, St. Petersburg, FL 33701.

E-mail: nschmidt@marine.usf.edu cholera diarrhea in Lima, Peru, during the 1997-98 El Niño event.

Although regional and hemispherical studies of climate variability such as ENSO provide a broad picture of potential impacts, they do not adequately address the scale of variability at which decisions are made. Effective planning and management of not only natural disasters but also the impacts of climate-related variability on agriculture, tourism, water resources, and human health occur mostly at the county and community levels. In Florida, where the economy is strongly based in the tourism and agricultural sectors and where coastal communities are experiencing unprecedented population growth, linking larger-scale regional patterns of climate variability to local impacts/conditions is particularly relevant.

\section{Examples of local-scale impacts in Florida}

Understanding local ENSO patterns, on the scale of counties or drainage basins, has application for Florida's economy. Florida's two most important economic sec- 
tors are tourism and agriculture, both of which are highly affected by rainfall and river discharge in coastal areas. For example, Hansen et al. (1999) find that during the winter season in Florida, quarterly yields, prices, production, and value for crops such as tomato, bell pepper, sweet corn, and snap bean are related to ENSO phase (and its relationship to rainfall, temperature, and solar radiation). Given the fact that Florida vegetable growers are the dominant and at times only source of fresh winter vegetables grown in the United States, characterizing the variability of precipitation in Florida benefits producers and consumers alike. Improvements in the forecasting accuracy of ENSO coupled with an understanding of how the local area responds to ENSOrelated phenomena hold forth the possibility of tailoring crop management to anticipated conditions, thereby improving or maintaining yields (Brown et al. 1986; Hansen et al. 1998). This approach has been demonstrated reasonably well for other areas of the United States, particularly for long-range streamflow forecasting (Piechota and Dracup 1999). Florida's other economic mainstay, tourism, is also affected by climatic anomalies associated with ENSO. For example, during the 1997-98 El Niño, elevated rainfall and cloudiness during the prime winter tourist months led to depressed revenues from tourism in the St. Petersburg, Florida, area, as evidenced by hotel occupancy rates (Albright 1998).

Water resources and human health are also potentially influenced by climate variability such as ENSO. Florida has experienced a $600 \%$ increase in population since 1940 and now has over 15 million residents, most of whom are concentrated in southern Florida's coastal counties. Hand-in-hand with burgeoning coastal populations comes the necessity of managing and maintaining coastal waters that are increasingly stressed by human impacts. For example, increased wastewater originating from treatment plants and septic tanks, increased biosolids loads at treatment plants, and higher volumes of urban nonpoint runoff all result from population growth in coastal communities (the National Oceanic and Atmospheric Administration 1998). Furthermore, urbanization will continue to alter coastal watersheds and freshwater flows to estuaries, such as Florida's Tampa Bay and Charlotte Harbor, as rural lands are converted to housing developments and river flows are diverted to meet the freshwater needs of the growing population.

Human impacts on the estuarine environment often are associated with deteriorating water quality and increased risks to human health. Public health issues have been highlighted by the Environmental Protection Agency's (EPA) Clean Water Initiative as a result of poor environmental conditions and microbial contaminants in coastal waters due to increased population growth and urbanization (Environmental Protection Agency 1999).

The vulnerability of coastal waters to conditions associated with human health risks also is exacerbated by unfavorable weather conditions, such as increased precipitation and river flow. High levels of enteric pathogens are associated with heavy rains and elevated river flow (Ferguson et al. 1996; Goyal et al. 1978; Wyer et al. 1995; Barbé and Francis 1995). By understanding how climatic variability influences precipitation and river flow, managers and planners can anticipate risk of exposure and/or illness and provide appropriate countermeasures (i.e., beach closings or warnings). Climate variability, such as ENSO and the North Atlantic oscillation, plays an important role in moderating precipitation (e.g., Ropelewski and Halpert 1986; Gershunov and Barnett 1998; McCabe and Dettinger 1999). Although the relationship between precipitation and ENSO events has been broadly demonstrated within Florida and for the southeastern United States, detailed local analyses are not available for most areas. In addition, impacts of ENSO-related variability in precipitation on river flow in urban watersheds are not widely known but potentially impact water quality and human health.

The objectives of this paper are three-fold.

1) To examine how seasonal rainfall in Florida responds to ENSO. Much research has focused on the relationship between precipitation and ENSO at global, hemispherical, and regional scales. Many of these analyses have included Florida (e.g., Ropelewski and Halpert 1986, 1996; Livezey et al. 1997; Gershunov and Barnett 1998; Livezey and Smith 1999); however, little has been done to examine in detail the patterns of rainfall within Florida, which may reflect both large-scale and local effects due to its subtropical location and proximity to both the Gulf of Mexico and the Atlantic Ocean. Both drought and prolonged heavy rainfall potentially have negative impacts on many aspects of Florida's economy and quality of life.

2) To examine how river flow in Florida responds to ENSO, with respect to seasonal precipitation patterns. In particular, the relationships between ENSO, rainfall, and river discharge in south-central Florida are assessed. The numerous rivers and streams in this area discharge not just water, which effects salinity regimes in coastal areas, but also urban, rural, and industrial pollutants into Florida's bays and coastal beach areas. This has implications for Florida's coastal water quality, particularly with regards to public swimming areas and shellfish harvesting (Lipp et al. 2000, manuscript submitted to Estuaries).

3) To document local climate-related variability in precipitation and river flow using data and techniques that are accessible to local planners and managers. Because decisions regarding strategies for responding to adverse conditions associated with climate variability are made at the local level, information pertinent to regional and local-scale impacts are necessary. 
We focus on the extreme phases of ENSO, based on Niño-3.4 sea surface temperature anomalies (SSTAs) from the equatorial Pacific. The selected methodology statistically examines the relationship between seasonal ENSO SSTA values and precipitation in Florida. For south-central Florida, the relationship between seasonal ENSO SSTA values and river flow is evaluated at lags of up to three months. Section 2 provides pertinent background information about ENSO and Florida. Section 3 presents the data used and describes the methodology for analysis. Results and discussion are presented in sections 4, 5, and 6, and a brief summary follows in section 7 .

\section{Background}

\section{a. ENSO teleconnections}

ENSO teleconnections with precipitation and streamflow in the United States during the winter include an equatorial (poleward) displacement of the midlatitude jet, which increases (decreases) frontal precipitation in the southeastern United States during El Niño (La Niña) events (Ropelewski and Halpert 1986, 1989; Kiladis and Diaz 1989). Additionally, moisture is advected from the tropical Pacific by the subtropical jet stream into the southeastern United States during El Niño winters (Ropelewski and Halpert 1986). Hoerling et al. (1997), however, find a large nonlinear component in North American climate anomalies, with a phase shift in El Niño anomaly patterns that is not present (or weak) in La Niña patterns. In the southeastern United States, summer precipitation and streamflow are affected by convectional and tropical storms; during El Niño (La Niña) years, tropical storm development decreases (increases; Gray 1984; Bove et al. 1998). Precipitation and streamflow, consequently, during El Niño (La Niña) summers and falls are more (less) likely to be the result of highly localized convective storms.

\section{b. ENSO and Florida}

In general, winters in the southeastern United States tend to be cooler and wetter during El Niño years and warmer and drier during La Niña years (Ropelewski and Halpert 1986, 1996; Kiladis and Diaz 1989; Sittel 1994a,b; Livezey et al. 1997; Gershunov and Barnett 1998; Livezey and Smith 1999). These patterns are strongest in the fall and winter.

There are several studies that report, as part of larger regional or hemispherical analyses, associations between precipitation and ENSO for Florida (Sittel 1994a; Livezey et al. 1997). ${ }^{1}$ Hanson and Maul (1991) focus

\footnotetext{
${ }^{1}$ References to Livezey et al. (1997) also include information presented by the authors online at http://www.cpc.ncep.noaa.gov/ products/, titled "El Niño-Southern Oscillation," and its associated links, which extends and complements Livezey et al. (1997). See Climate Prediction Center (2000) for additional information.
}

specifically on Florida; however, their methodology for classifying El Niño episodes is substantially different from that used in this research. Although all these analyses agree broadly for seasons such as winter, there are substantial differences in their interpretations of the geographic characteristics of seasonal precipitation in Florida with respect to ENSO. Complicating comparisons with their results is the variability in their approaches to classifying ENSO events, to the number of stations examined within Florida, to dividing Florida up geographically, and to categorizing changes in precipitation (e.g., "anomalously high" vs "very wet"). For example, Sittel (1994a) bases his analyses on precipitation data from only eight stations within Florida whereas Livezey et al. (1997) composite many stations into Florida's four Climate Districts. By focusing on precipitation within Florida, this research clarifies many of the conflicting interpretations presented in past studies. A summary of the results of these studies follows.

Hanson and Maul (1991) report that precipitation during El Niño events is anomalously high during the winter and spring in Florida. During the summer, precipitation anomalies tend to be small and, during the fall, inconsistent. Sittel (1994a) finds that for El Niño years, all but Florida's southernmost regions are wetter than normal during the fall. In contrast, Livezey et al. (1997) find that during November-December, all of Florida is wetter than normal and southernmost Florida is very wet. El Niño winters are unambiguously wetter than normal in Florida, with southern Florida showing the strongest response (Sittel 1994a; Livezey et al. 1997). During El Niño spring, Sittel (1994a) finds that north and central Florida are wetter than normal and southern Florida is drier. Florida experiences drier than normal conditions during El Niño summers (Sittel 1994a).

Florida's La Niña precipitation is not a symmetric counterpart to El Niño except during the winter, when Florida is drier overall than normal (Sittel 1994a; Livezey et al. 1997). During La Niña spring, Livezey et al. (1997) find southernmost Florida to be drier than normal whereas central and north Florida experience normal precipitation. Sittel (1994a), however, reports that Florida receives less precipitation than normal, with south Florida having a high probability of a dry spring. La Niña summer is characterized in a similar fashion by Sittel (1994a): Florida is drier than normal, with the pattern strongest in south Florida. Both Livezey et al. (1997) and Sittel (1994a) find Florida to be drier than normal during La Niña fall; however, Sittel (1994a) reports that south Florida experiences normal precipitation.

Streamflow, which integrates precipitation over drainage basins, responds to precipitation by a temporally variable combination of runoff and groundwater inputs. Analyses of the relationship between El Niño and regional streamflow in the southeastern United States demonstrate a similar, but lagged, response to the precipitation (Kahya and Dracup 1993). Similar relation- 


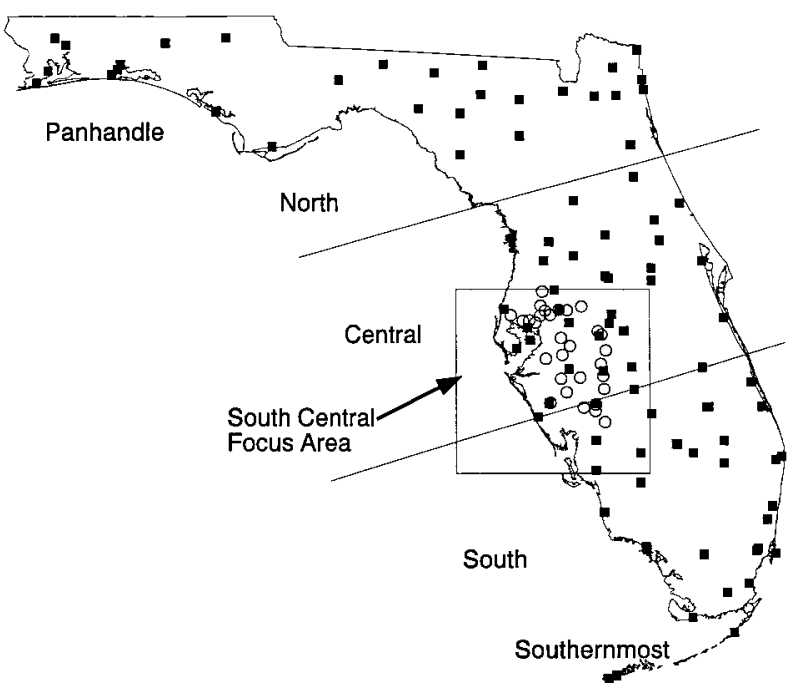

FIG. 1. Map of Florida, with precipitation stations indicated by filled squares and river gauge stations by open circles. Geographic designations used in this paper are also shown.

ships between ENSO and streamflow in South America have also been explored (Depetris et al. 1996; Compagnucci and Vargas 1998). Likewise, Zorn and Waylen (1997) find wintertime responses in their analyses of mean monthly streamflow and ENSO in north-central Florida, with lags of one to two months. The duration of the response is longer during El Niño than during La Niña events. In addition, they document a late summer ENSO response in streamflow, which they tentatively relate to the increased (decreased) frequency and intensity of tropical storms impacting north-central Florida under La Niña (El Niño) conditions. Sun and Furbish (1997) examine annual precipitation and river discharge patterns in Florida in response to ENSO; they find wet (dry) conditions and higher (lower) stream discharge in El Niño (La Niña) years. In addition, they conclude that reservoir effects might cause a six-month to 1-year delay in annual stream discharge response to SST signals. The lag reflects the relationship between streamflow and the groundwater table-in Florida most streams gain water from aquifers, and their discharge directly reflects groundwater levels (Sun and Furbish 1997).

\section{c. The focus area}

Florida is divided into two meteorologic and hydrologic regimes, based primarily on latitude, with different seasonal patterns. North Florida and the Panhandle area (Fig. 1) experience winter maximums in precipitation and streamflow due to the frontal systems that impinge southward into the northern parts of the state. This frontal influence decreases to the south, where summer maximums in precipitation and river flow are generated from convectional and tropical storms. Rainfall accounts for

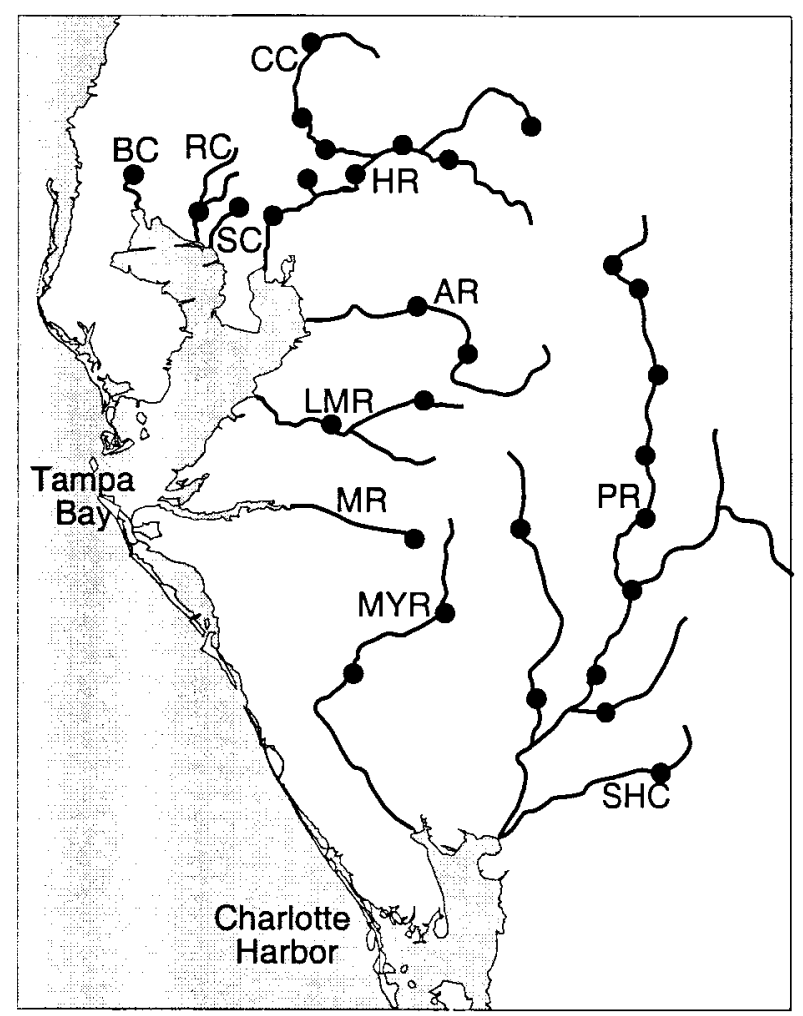

FIG. 2. Map of south-central Florida focus area, with river gauge stations (closed circles) and rivers identified as follows: BC, Brooker Creek; RC, Rocky Creek; SC, Sweetwater Creek; HR, Hillsborough River; CC, Cypress Creek; AR, Alafia River; LMR, Little Manatee River; MR, Manatee River; MYR, Myakka River; PR, Peace River; and SHC, Shell Creek.

nearly all of the precipitation in Florida and averages annually about $127-152 \mathrm{~cm}(50-60 \mathrm{in}$.).

The Tampa Bay and Charlotte Harbor regions are located in south-central Florida on the Gulf of Mexico coast (Fig. 1) and experience maximum precipitation and river flows during the summer months in response to convectional storms and, less frequently, tropical storms. In this study, river flow data are examined from 11 of the major drainage basins in Tampa Bay and Charlotte Harbor (Fig. 2). The Tampa Bay drainage area encompasses $3550 \mathrm{~km}^{2}$ and contains a surficial aquifer that is recharged by local precipitation as well as deeper aquifers (Southwest Florida Water Management District 1998). A number of springs also contribute to the hydrologic regime, and most of the rivers are categorized as gaining rivers. Land use within the region is variable; residential and commercial use dominate the coastal and estuarine areas and agriculture and phosphate mining, the more rural, interior areas. As a result, most of the larger watersheds experience rural influences in their upstream portions and more urban influences downstream. Land-use impacts and diversions, dams, and channel hardening all combine to create river flow re- 
TABLE 1. Classification of seasons based on ENSO phase.

\begin{tabular}{|c|c|c|c|}
\hline & El Niño & Neutral & La Niña \\
\hline $\begin{array}{l}\text { Winter } \\
\text { JFM }\end{array}$ & $\begin{array}{l}1958,1966,1969,1970,1973,1983 \\
1987,1992,1995,1998\end{array}$ & $\begin{array}{c}1952,1953,1954,1957,1960,1961 \\
1962,1963,1965,1967,1972,1979 \\
1981,1982,1990,1991,1994,1997\end{array}$ & $\begin{array}{l}1955,1956,1971,1974,1976,1985 \text {, } \\
\quad 1989\end{array}$ \\
\hline $\begin{array}{l}\text { Spring } \\
\text { AMJ }\end{array}$ & $\begin{array}{l}1958,1969,1982,1983,1987,1992 \\
\quad 1993,1997\end{array}$ & $\begin{array}{l}1951,1952,1954,1959,1960,1961, \\
1962,1963,1967,1968,1970,1973 \\
1976,1977,1978,1979,1980,1981 \\
1984,1986,1990,1994,1995,1996 \\
1998\end{array}$ & $\begin{array}{l}1950,1988(1955,1956,1965,1971, \\
1974,1975,1985,1989)^{*}\end{array}$ \\
\hline $\begin{array}{l}\text { Summer } \\
\text { JAS }\end{array}$ & $\begin{array}{l}1957,1963,1965,1969,1972,1982, \\
\quad 1987,1991,1997\end{array}$ & $\begin{array}{l}1952,1958,1959,1960,1961,1962 \\
1966,1978,1979,1980,1981,1983 \\
1984,1985,1989,1990,1992,1995 \\
1996\end{array}$ & 1955, 1970, 1973, 1975, 1988, 1998 \\
\hline $\begin{array}{l}\text { Fall } \\
\text { OND }\end{array}$ & $\begin{array}{l}1951,1957,1963,1965,1968,1969 \\
\text { 1972, 1976, 1977, 1982, 1986, 1987, } \\
\text { 1991, 1994, 1997 }\end{array}$ & $\begin{array}{l}1952,1956,1958,1959,1960,1961 \\
1966,1967,1978,1980,1981,1985 \\
1989,1992,1996\end{array}$ & $\begin{array}{c}1950,1954,1955,1964,1970,1973, \\
1975,1984,1988,1995,1998\end{array}$ \\
\hline
\end{tabular}

* La Niña spring was expanded to include 5-month running averages in Niño-3.4 SSTAs with values less than or equal to -0.40. This was done to create a subsample size large enough for statistical analysis.

gimes in both Tampa Bay and Charlotte Harbor that are highly affected by human influences.

\section{Data and methods}

The approach used in this study was to analyze the statistical dependency of monthly and seasonal precipitation and river discharge levels on ENSO phases, using historical records for over 100 stations in Florida, focusing on south-central Florida's river discharge (Fig. 1).

\section{a. Data}

\section{1) ENSO}

Using the Climate Prediction Center's Niño-3.4 sea surface temperature (SST) monthly anomaly indices, seasons from 1950 to 1998 were classified as extreme or neutral. ENSO extreme seasons are defined to occur when the 5-month running average, centered around the season, of the Niño-3.4 SSTAs exceed $|0.7|^{\circ} \mathrm{C}$. Neutral ENSO seasons are defined to occur when the 5-month running average, centered around the season, falls between $\pm 0.4^{\circ} \mathrm{C}$ (Table 1). For all seasons except La Niña spring, these thresholds exclude questionable ENSO events while providing an adequate number of cases for analyses for all ENSO phase seasons. This is in good agreement with Gershunov and Barnett (1998) who define El Niño (La Niña) years as those years in which the SSTA from the same region were more than one standard deviation above (below) the mean. This is also in good agreement with Sittel (1994a), who defines El Niño (La Niña) years based on the 5-month running mean of the Japanese Meteorological Agency SSTA. The mean must be greater (less) than $0.5^{\circ} \mathrm{C}$ for six consecutive months starting in the fall for a year to be considered an El Niño (La Niña) year. Our approach to classifying ENSO events was chosen for several reasons: there is no one generally accepted classification scheme, our scheme captures the most widely recognized and accepted ENSO events, and our scheme is simple to apply to the SSTA dataset.

\section{2) Precipitation AND Discharge}

Sources for precipitation and river discharge data in Florida are summarized in Table 2. Only stations with more than 300 months (approximately $25 \mathrm{yr}$ ) of data were used from each dataset; most of the stations analyzed had over 500 months of data. Monthly mean values were calculated from daily observations only if valid data were available for every day of the month. Similarly, seasonal precipitation totals and mean dis-

TABLE 2. Description of data.

\begin{tabular}{llccc}
\hline \hline \multicolumn{1}{c}{ Source } & \multicolumn{1}{c}{ Type } & $\begin{array}{c}\text { No. of } \\
\text { stations }\end{array}$ & $\begin{array}{c}\text { Max period } \\
\text { of record }\end{array}$ & $\begin{array}{c}\text { Mean no. of } \\
\text { months/station }\end{array}$ \\
\hline $\begin{array}{l}\text { National Weather Service } \\
\text { Global Surface Summary of Day }\end{array}$ & Monthly precipitation & 22 & $1950-98$ & 513 \\
$\begin{array}{c}\text { National Climate Data Center } \\
\text { Daily Surface Data }\end{array}$ & Monthly precipitation & 42 & $1950-98$ & 528 \\
$\begin{array}{l}\text { South Florida Water } \\
\quad \text { Management District }\end{array}$ & Monthly precipitation & 30 & $1950-98$ & 523 \\
U.S. Geological Survey & Monthly mean daily discharge & 30 & $1950-98$ & 442 \\
\hline
\end{tabular}


charges were calculated for seasons that had valid monthly values for all three months of the season.

\section{b. Analyses}

To test the hypothesis that ENSO phase affects seasonal rainfall and river flow in Florida, precipitation totals and mean daily river discharge during El Niño (EN) and La Niña (LN) seasons were compared to neutral conditions using an approximate randomized difference of means test (Noreen 1989). These computerintensive tests generate the probability distribution of the test statistic by recomputing it for many $(>100)$ artificially constructed datasets and can be used to assess significance under minimal assumptions. The observations that are tested do not need to meet the normal distribution criteria of conventional parametric statistics, nor do they need to constitute a random sample. In addition to avoiding some of the assumptions required by conventional statistical methods, approximate randomization methods maximize the ability to discriminate between hypotheses because the sampling distribution is known (Noreen 1989).

The significance of each randomized analysis was evaluated at the $95 \%$ confidence level $(\alpha=0.05)$ after 10000 iterations. Due to the paucity of LN springs from 1950 to 1998 (Table 1; only two in almost $50 \mathrm{yr}$ ), this ENSO season was expanded to include weaker ENSO events. This is indicated in parentheses in Table 1 and includes springs with 5-month running average SSTA less than or equal to $-0.4^{\circ} \mathrm{C}$. Additionally, if a station was missing monthly data such that less than three cases of a particular ENSO season were recorded, that season was not examined. This restriction tended to impact LN seasonal analyses, which typically had smaller numbers of cases than the EN seasons.

\section{Precipitation results}

Figures $3 \mathrm{a}-\mathrm{h}$ illustrates the ENSO-related rainfall patterns in Florida for winter, spring, summer, and fall. In the following discussion of these patterns, the significance of the difference between mean rainfall for a season and rainfall during the neutral season is considered, as is the overall rainfall pattern (greater than or less than neutral rainfall). Variability in rainfall patterns between closely located stations is attributed to heterogeneous nature of precipitation that is somewhat smoothed out by using mean rainfall over the period of record, but not as much as it would be if data were combined over geographic regions (such as Climate Districts).

\section{a. Winter}

For winter months, total seasonal precipitation showed strong responses to ENSO phase. Statewide, EN (LN) winter precipitation totals were higher (lower) than during neutral winters. During neutral winters, Florida experienced a SE-NW trend in precipitation, with the southern portions of the state receiving less precipitation (10-30 cm; 4-12 in.) than the northern portions (40$51 \mathrm{~cm} ; 16-20$ in.). This pattern was reversed during EN winters, when stations in southern Florida experienced as much as $50 \%-150 \%$ more rain, and accentuated during LN winters, when southern Florida received 50\%$100 \%$ less rain (Figs. 3a,b). Overall, $75 \%$ of the stations experienced EN winter rainfall totals that were significantly greater than neutral winter rainfall and $92 \%$ received significantly less rainfall during LN winters.

\section{b. Spring}

The response of precipitation to spring ENSO conditions was variable. During neutral springs, Florida's precipitation was fairly uniform, with total precipitation during April, May, and June typically 20-40 cm (8-16 in.). This pattern did not change dramatically during EN springs; the majority of stations exhibited -50 to $50 \%$ change in precipitation levels (Fig. 3c) Only 10 stations $(11 \%)$ had significantly higher levels of precipitation during EN springs compared to neutral springs. Southernmost Florida showed the strongest response both in terms of percentage change (up to 100\%) and significance (6 of the 10 stations exhibiting a significant relationship between precipitation and ENSO SSTA are in southernmost Florida). The Panhandle and northern Florida also had higher levels of precipitation although not significantly higher than during neutral springs.

Due to the paucity of LN springs, the classification requirements were relaxed to include springs whose 5-month running mean of Niño-3.4 SSTA were $<0.4{ }^{\circ} \mathrm{C}$ (instead of $0.7^{\circ} \mathrm{C}$ ). During LN springs, Florida was overall drier than neutral, but rarely significantly so (Fig. $3 \mathrm{~d})$. Thirteen percent of the stations were significantly drier at the $95 \%$ confidence level; this increased to $22 \%$ at the $90 \%$ confidence level. All stations with significant differences from neutral precipitation levels are found in southern Florida. The Panhandle was wetter than during neutral springs; however this pattern may not be real: using the stricter classification requirements, $90 \%$ of the stations experienced drier conditions during LN springs, including all but one station in the Panhandle.

\section{c. Summer}

Florida experienced its highest precipitation levels in the summer as a result of tropical storms and local convective thunderstorms. Although precipitation levels tended to be lowest in the Panhandle, overall levels ranged from 40 to $61 \mathrm{~cm}$ (16 to 24 in.). During EN and LN summers this pattern did not appreciably change (Figs. 3e,f), except that during LN summers the Panhandle and the western part of northern Florida received significantly more precipitation. Of the 12 stations in the Panhandle region, 6 received significantly more rain 
during LN summers than during neutral summers; this number increased to 7 at the $90 \%$ confidence level.

\section{d. Fall}

Precipitation levels were uniform statewide during neutral falls, with most of the state receiving between 10 and $20 \mathrm{~cm}$ (4 and 8 in.) of rainfall. There was a slight tendency for the Panhandle to be wetter. Precipitation during EN falls was higher statewide, with both the greatest and the most significant deviations from neutral precipitation occurring in the central and southern parts of the state (Fig. 3g). Fifty-seven percent of the stations in central Florida received significantly higher rainfall during EN falls than during neutral falls; this went up to $69 \%$ if stations that were significant at $\alpha=0.10$ were included. Precipitation in the Panhandle did not vary much or significantly from neutral fall levels.

In contrast, $65 \%$ of the stations received less precipitation during LN falls than during neutral falls. However, LN fall precipitation levels were almost indistinguishable from those during neutral falls; the variability was low ( -50 to $50 \%$ deviation from neutral precipitation) and few stations (12\%) showed a significant change from neutral precipitation levels (Fig. 3h).

\section{River discharge results}

The river discharge dataset comprises 30 stations in 11 drainage basins in south-central Florida: Brooker Creek, Rocky Creek, Sweetwater Creek, Cypress Creek, Hillsborough River, Alafia River, Little Manatee River, Manatee River, Peace River, Myakka River, and Shell Creek (Fig. 2). These drainage basins vary substantially in size and characteristics, with some being spring-fed, some dammed, some channelized in places, and some relatively pristine. Land use ranges from agricultural to fully urban to mixed drainages. Because the characteristics of an individual drainage impacts the timing of its response to precipitation, analyses were lagged up to 2 months in order to accommodate the uniqueness of each basin.

Figures $4 \mathrm{a}-\mathrm{h}$ illustrate the ENSO-related river flow patterns in the focus area for winter, spring, summer, and fall. In the following discussion of these patterns, the significance of the difference in mean river flow for an El Niño or La Niña season versus river flow during the neutral season is considered, as is the overall river flow pattern (higher than or lower than neutral river flow levels). Variability in river flow patterns between stations within the same drainage basin is attributed to both the spatially heterogeneous nature of precipitation events and human impacts, such as dams, diversions, and discharges. River flow patterns in adjacent sub-basins may show opposite responses to ENSO conditions; see, for example, the two stations along the Little Manatee River, which are separated by only a few miles. The upstream station maintains elevated river flow lev- els during La Niña falls, winters, and springs whereas the downstream station experiences lower flow levels (Figs. 3c,d,g, and h). The upstream station is in a subbasin that is dominated by phosphate mining and in dry seasons actually experiences increased runoff from groundwater discharges (Flannery et al. 1992). Similarly, base flows in sub-basins dominated by agriculture have increased during dry seasons over the past few decades because of runoff associated with groundwaterbased irrigation, (M. S. Flannery 2000, personal communication). In these examples, local river flow responses to ENSO conditions are mediated by human impacts.

It is important to note that our analyses cannot differentiate unequivocally between local river flow responses to ENSO conditions and to human impacts. It appears that the ENSO influence is strong enough in winter to overwhelm any others but even this is unknown in a formal sense, given the "wild card" of human intervention. Therefore, human impacts in our urban and suburban focus area may mask the influence of climate variability on seasonal streamflow.

\section{a. Winter}

During winter months, mean river discharge levels in the Tampa Bay and Charlotte Harbor regions showed strong responses to ENSO phase (Figs. 4a,b). Sixtyseven percent of the stations had significantly higher mean discharge levels during EN winters compared to neutral winters; the percentage increases to $83 \%$ at the $90 \%$ confidence interval. Discharge levels were typically over $200 \%$ greater than neutral during EN winters and were lagged 1-2 months relative to the ENSO season. In contrast, mean discharge levels during LN winters were typically $70 \%$ lower than during neutral winters, although the difference in mean discharge during LN and neutral winters was significant in only $69 \%$ of the stations $(73 \%$ at the $90 \%$ confidence interval). Again, most stations showed the strongest response at lags of 1-2 months.

\section{b. Spring}

For EN springs, mean discharge levels were 136\% greater compared to neutral springs; however, the difference in mean discharge levels for EN and neutral springs was rarely significant (23\% of stations; Fig. 4c). Typical lags were $0-1$ months relative to the ENSO season. Overall, $87 \%$ of the stations exhibited greater mean discharge levels during EN springs than during neutral springs.

Although almost all $(90 \%)$ of the stations exhibit lower than neutral flow levels during extreme LN springs, there were not enough extreme LN springs for statistical analyses. After substituting the broader classification of LN springs (Table 1), mean river discharge was also depressed (58\% lower than during neutral springs; Fig. 


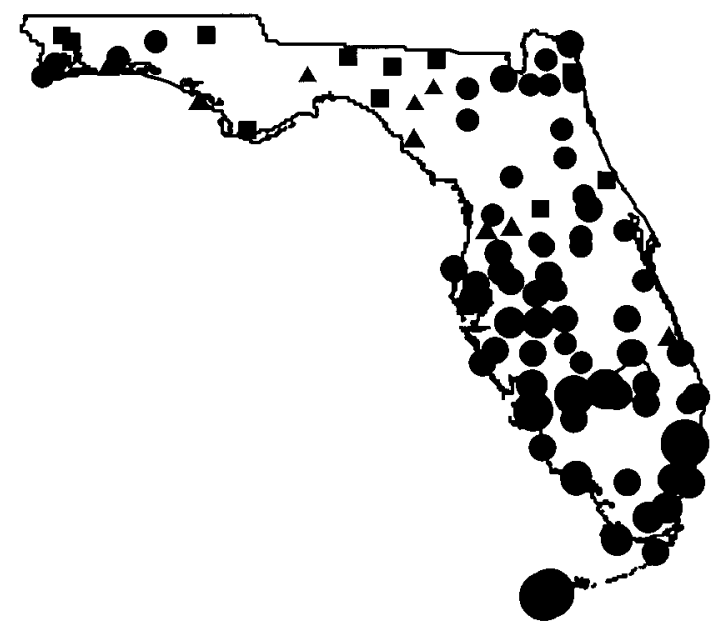

A. El Niño Winter

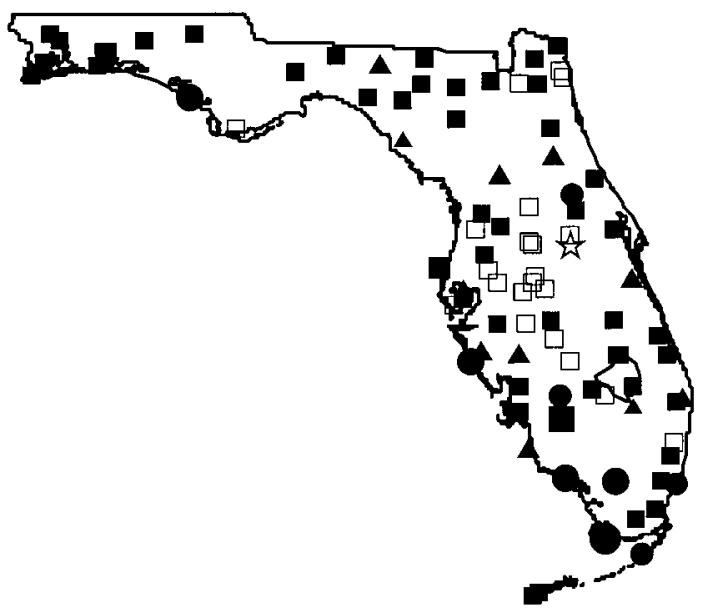

C. El Niño Spring

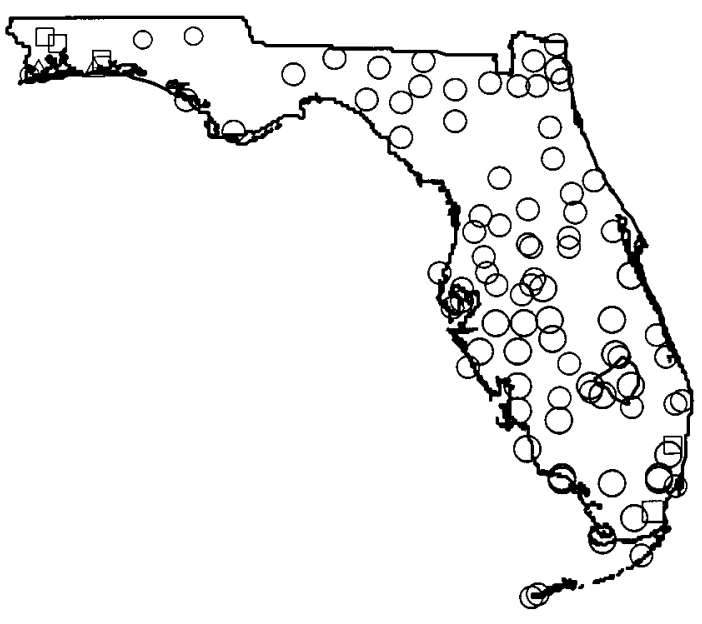

B. La Niña Winter

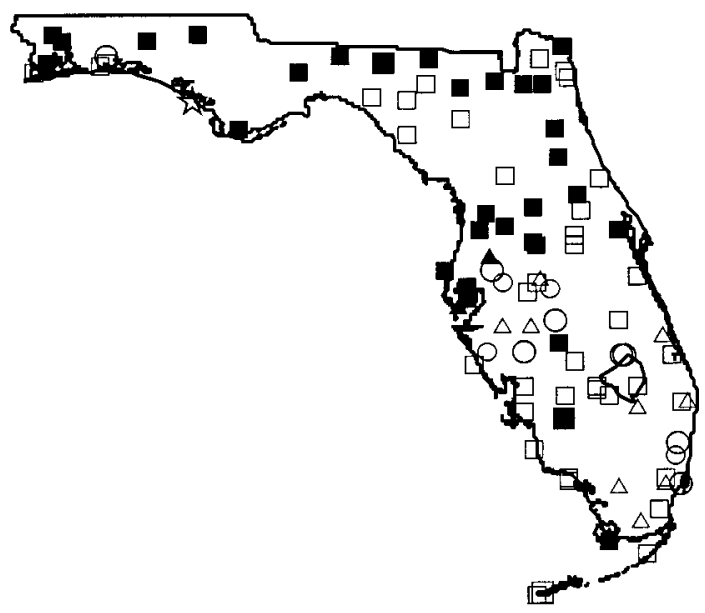

D. La Niña Spring

Significance Level

$\%$ Deviation from Neutral Precipitation

$$
\begin{aligned}
& \square \triangle 0^{-75--50} \\
& \square \Delta \quad 0^{-49-25} \\
& \square \Delta \quad 0 \quad-24-0.01 \\
& \text { 放文放0 }
\end{aligned}
$$

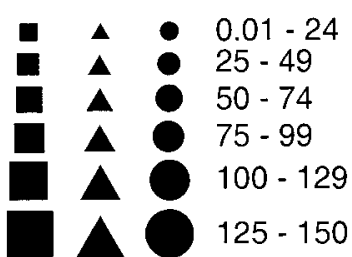

$<0.05$

A $<0.10 \&>0.05$

not significant

FIG. 3. (a)-(h) Seasonal ENSO maps of mean precipitation in Florida, showing the significance level for each stations for the approximate randomized difference of means test and the percent deviation from mean neutral season precipitation.

4d). This decrease in river flow was significant for $50 \%$ of the stations; this increased to $63 \%$ at the $90 \%$ confidence interval. Lags of $0-1$ month relative to the ENSO season were most common.

\section{c. Summer}

Response was typically not significant for either EN or LN summers; however, mean discharge levels were 


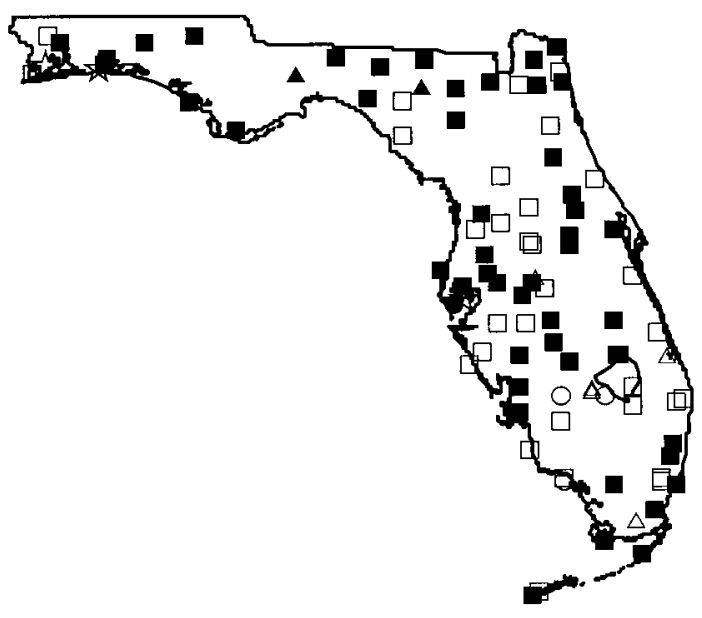

E. El Niño Summer

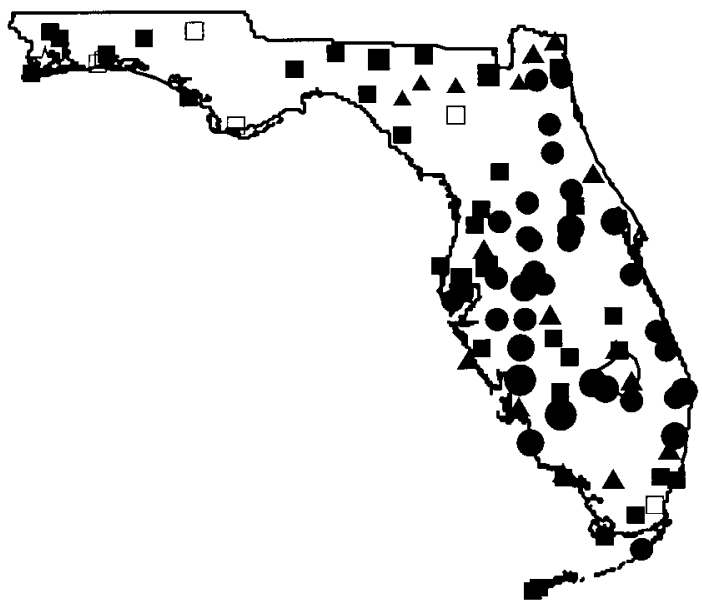

G. El Niño Fall

\% Deviation from Neutral Precipitation

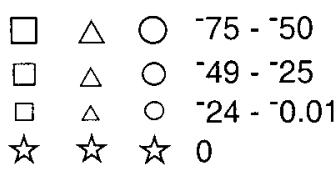

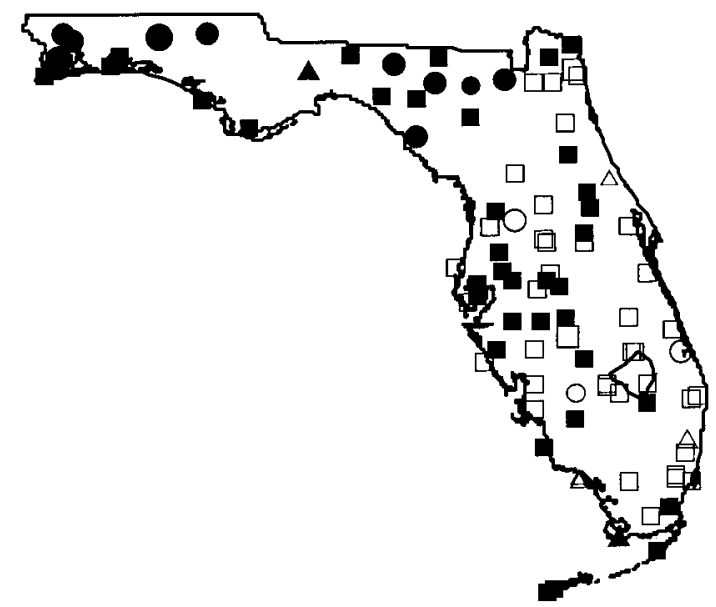

F. La Niña Summer

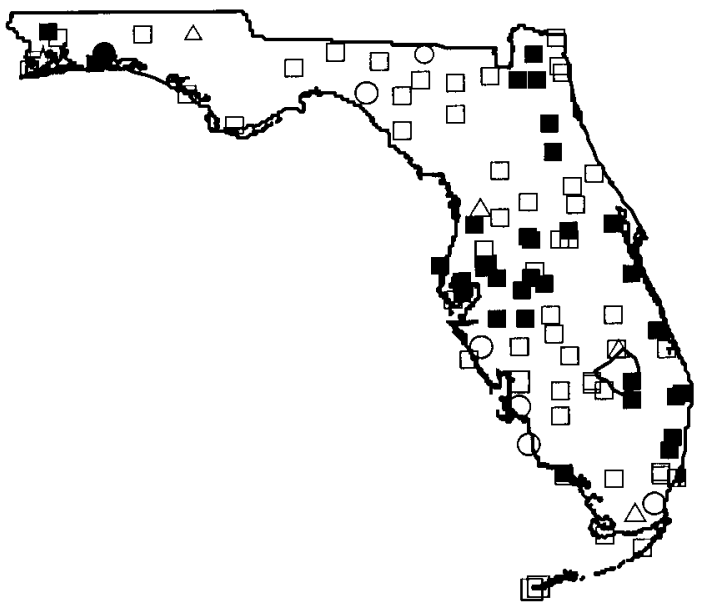

H. La Niña Fall

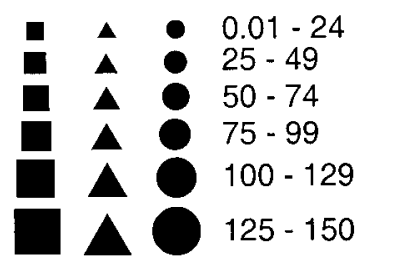

Significance Level

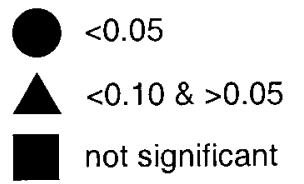

FIG. 3. (Continued)

lower than during neutral summers (Figs. 4e,f). During EN summers, $67 \%$ of the stations and during LN $57 \%$ of the stations experienced depressed mean river flow levels. Lags from ENSO season were typically 0-1 month for both EN and LN summers.

\section{d. Fall}

Higher mean river discharge levels occurred during EN falls; flows averaged $130 \%$ above levels during neutral falls (Fig. 4g). Sixty-seven percent of the stations 
experienced significantly higher flow levels; this increases to $83 \%$ at the $90 \%$ confidence level. Most stations showed the strongest response at lags of 1-2 months. During LN falls, 20\% of the stations experienced significantly higher river discharge levels; some of which were greater than $500 \%$ above neutral fall levels (Fig. 4h). At the 90\% confidence level, 30\% of the stations experienced higher discharge levels. Overall, however, the stations were almost equally divided between those with higher and those with lower discharge levels, and the majority of stations experienced levels within $50 \%$ of neutral levels. Stations with higher discharge levels during LN falls tended to have 0-1month lags from the ENSO season whereas those with lower levels tended to have 1-2-month lags.

\section{Discussion}

Seasonal precipitation and river discharge both exhibit strong responses to ENSO, as shown by their relationships to Niño-3.4 SSTA. In Florida, precipitation levels are overall higher (lower) during EN (LN) events, although these responses do not necessarily mirror one another during seasons such as spring and fall. In southcentral Florida, river flow responds in a more complicated fashion to ENSO events, with individual stations characterized by varying lags and strengths of response. Discharge levels are elevated during EN falls and winters; this pattern may persist in EN springs. Extreme La Niña winters and springs typically have lower discharge levels and this pattern extends into the summer for many stations.

Because our analyses test only local significance, we limit the discussion to suggestions about geographical patterns in Florida with respect to ENSO-related rainfall and river flow, similarities and differences between our results and those discussed in the introduction, and possible mechanisms that might account for these patterns.

\section{a. Seasonal precipitation in Florida}

Comparison of our results with those of two other studies that include detailed seasonal analyses of rainfall in Florida demonstrates broad agreement, but considerable discrepancies in terms of geographical variation, especially during La Niña conditions. Similar to our results, Livezey et al. (1997) find a NW-SE trend in the elevated precipitation associated with El Niño falls and winters. South and central Florida, with their normally lower winter precipitation levels, experience greater increases in rainfall during El Niño winters than does northern Florida and the Panhandle region. This broad geographical pattern is most likely the result of the southward displacement of frontal systems into southern Florida during El Niño winters (Ropelewski and Halpert 1986, 1989; Kiladis and Diaz 1989). For El Niño spring precipitation, Sittel (1994a) finds that central and northern Florida experience wet conditions and Hanson and Maul (1991) report that Florida is overall wetter. Our results, in contrast, suggest that the Panhandle region and southernmost Florida experience elevated precipitation levels whereas precipitation in central Florida is not affected. Our analyses show no clearcut geographic variability in precipitation levels during El Niño summers; Sittel (1994a), however, finds that Florida experiences drier than normal conditions. Precipitation during El Niño falls, as indicated by our results and those of Livezey et al. (1997), indicate that precipitation follows a similar, but weaker, trend as in El Niño winters. Sittel (1994a) finds the opposite trend for El Niño falls; his analyses indicate that southernmost Florida experiences normal levels of precipitation.

During La Niña winters, there is broad agreement that conditions in Florida are drier. Our results and those of Livezey et al. (1997) document a NW-SE trend, with rainfall in southernmost Florida more strongly depressed than rainfall in northern Florida and the Panhandle. This NW-SE trend, however, is not as pronounced as it is during El Niño winters. Our results suggest a different version of La Niña spring precipitation than do either Livezey et al. (1997) or Sittel (1994a). Statewide, Florida is drier than normal but not significantly drier. Livezey et al. (1997) find southern Florida drier but northern Florida about normal. Sittel (1994a) indicates that south Florida is drier than normal and has a high probability of being drier than normal during La Niña springs.

Conditions during La Niña summers do not vary significantly from neutral summers, except in the western part of northern Florida and in Panhandle area, which may be slightly wetter. Sittel (1994a) finds that north and central Florida are wetter and southern Florida is drier. During La Niña falls, our results suggest that there is a tendency for most of Florida to be slightly drier, with no strong geographical pattern. These depressed precipitation levels, however, are not significant at most stations. Livezey et al. (1997) find precipitation levels lower throughout Florida, with the driest conditions in southern Florida. Sittel (1994a) also finds conditions in Florida to be drier than normal during La Niña falls.

\section{b. Seasonal river flow in south-central Florida}

Seasonal river flow patterns represent a complex interaction between precipitation and river basin characteristics such as the groundwater table, aquifers, natural and human diversions such as swamps and dams, evapotranspiration, and soil moisture. These interactions, while filtering out the noisier, local aspects of rainfall, may create a more subtle ENSO signal that is lagged relative to rainfall. Our analyses represent a first attempt to document the relationship between ENSO and seasonal river flow in south-central Florida.

Our results for south-central Florida support previously reported relationships between El Niño (La Niña) and elevated (depressed) mean seasonal river flow in 
the winter in northern Florida (Zorn and Waylen 1997). River flow during El Niño springs is also generally elevated but more variably and less significantly; during La Niña springs, river flow levels are depressed. River flow levels during the summer are lower for both El Niño and La Niña; however, the number of stations with significant relationships is low. During the fall, river flow levels are elevated for both El Niño and La Niña, but more stations have significant relationships during El Niño falls (Figs. 4g,h). We tentatively explain the elevated river flow levels during fall as relating to increased tropical storm activity during La Niña and increased late fall frontal system precipitation during El Niño. Delays in the response of streamflow to sea surface temperature anomalies support this explanation; lags during El Niño falls are typically 1-2 months and during La Niña falls, 0-1 months. We would expect a faster response to the more intense tropical storm precipitation than to the frontal system rainfall. The monthly rainfall data from the Charlotte Harbor and Tampa Bay focus area also support this hypothesis. During El Niño falls, rainfall is elevated relative to neutral falls in November and December. The proposed explanation for the La Niña fall river flow pattern is more complicated. In the northern part of the focus area, rainfall levels tend to be elevated, although not typically significantly so, during La Niña springs, summers, and falls (Figs. 3d,f, and h). During persistent La Niña conditions, the drainage basins would receive elevated levels of rainfall for more than half of the year, cumulating in the significantly elevated river flow levels documented for La Niña falls (Fig. 3h). Also, rainfall during November, typically one of the driest months of the year in central Florida, is elevated in the northern part of the focus area and is similar to neutral levels in the southern part of the focus area during La Niña falls.

Focusing on south-central Florida and the Tampa Bay and Charlotte Harbor areas in particular, a plausible story can be constructed for the relationship between ENSO, precipitation, and river flow that uses the results of this research to add detail to the general scenarios for ENSO teleconnections already developed by others (i.e., Ropelewski and Halpert 1986, 1989). In fall and especially winter, the equatorial displacement of the subtropical jet stream under El Niño conditions increases frontal precipitation in the central and south portions of the state (Kiladis and Diaz 1989; Ropelewski and Halpert 1989). Although both winter and fall precipitation levels are low compared to summertime levels, during extreme El Niño falls and winters, precipitation levels may double. Locally, streams and rivers respond to the higher precipitation levels slowly, with a 1-2-month lag before flow levels rise to their highest. Levels remain high into the El Niño spring, despite precipitation levels that are average. By summer, when localized convective rainfall and tropical storms raise precipitation levels to their yearly highs, regardless of ENSO state, river flow levels also drop back to their neutral summer levels.
Although the opposite "story" can be constructed for La Niña teleconnections, the timing of the events tends to be different. Decreased frontal precipitation, due to the poleward displacement of the midlatitude jet, occurs during the winter and sometimes into the spring (Kiladis and Diaz 1989; Ropelewski and Halpert 1989). River flow levels are depressed, with lags of 1-2 months, during the winter and spring; this trend continues through the summer with almost no lag. Summertime precipitation levels are indistinguishable from neutral summer levels; that is to say, they are high. Fall river flow levels tend to be elevated relative to neutral fall levels in the northern part of the Tampa Bay and Charlotte Harbor focus area, due to persistently but not significantly higher rainfall levels during the preceding seasons. In the southern part of the focus area, river flow levels are depressed during the La Niña fall, and spring, summer, and fall precipitation levels are lower than or close to normal. It is interesting and important to note that our story does not (and cannot except in the broadest sense) take into account the impacts of humans on urban river flow patterns.

Interestingly, two areas in Florida stand out because they often do not respond in the same manner as the rest of the state to ENSO conditions: the Panhandle area, in extreme northwestern Florida, and southernmost Florida. The Panhandle area is not part of the Florida peninsula and precipitation patterns there correspond more closely to those of the Gulf of Mexico coastal states (Louisiana, Mississippi, and Texas). El Niño precipitation remains elevated in the spring, but is not significantly affected during the fall. La Niña patterns in the Panhandle also standout: summer precipitation is elevated, perhaps reflecting an increase in rainfall associated with tropical storms. Southernmost Florida, which includes the Everglades, the Miami-Dade area, and the Florida Keys, experiences more tropical influences than the rest of Florida. This area also exhibits anomalous ENSO-precipitation responses. The greatest increase in rainfall compared to neutral conditions occurs in southernmost Florida during EL Niño winter and spring whereas during El Niño fall the increase in rainfall is not as pronounced as it is in central Florida. During La Niña conditions, only winter rainfall is typically and significantly depressed in southernmost Florida; during the other seasons, levels are depressed but generally not significantly so.

These results for Florida confirm the temporal asymmetries in rainfall and river discharge associated with ENSO (Ropelewski and Halpert 1989; Kahya and Dracup 1993; Livezey et al. 1997; Montroy et al. 1998). Although Montroy et al. (1998) report essentially linear (symmetric) associations of precipitation and ENSO phases during the winter season, they also discuss nonlinear teleconnections during other months and seasons between the tropical Pacific Ocean sea surface temperature anomalies and precipitation in the southeastern United States. 


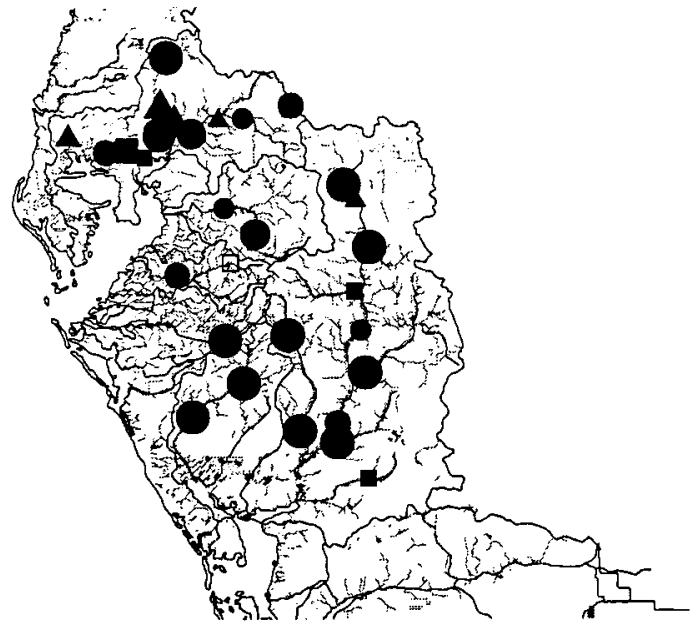

A. El Niño Winter

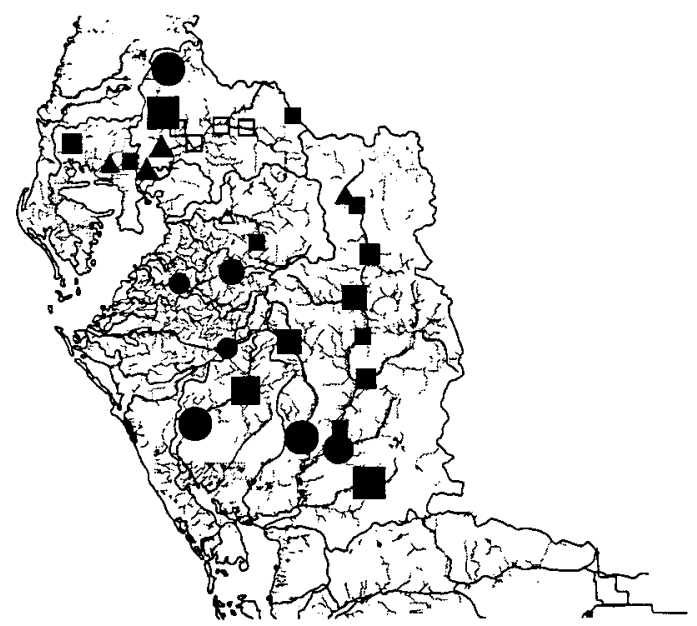

C. El Niño Spring

\% Deviation from Neutral Flow

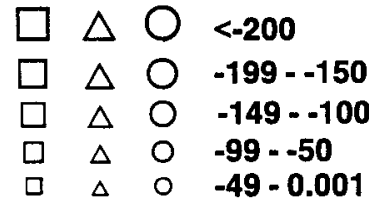

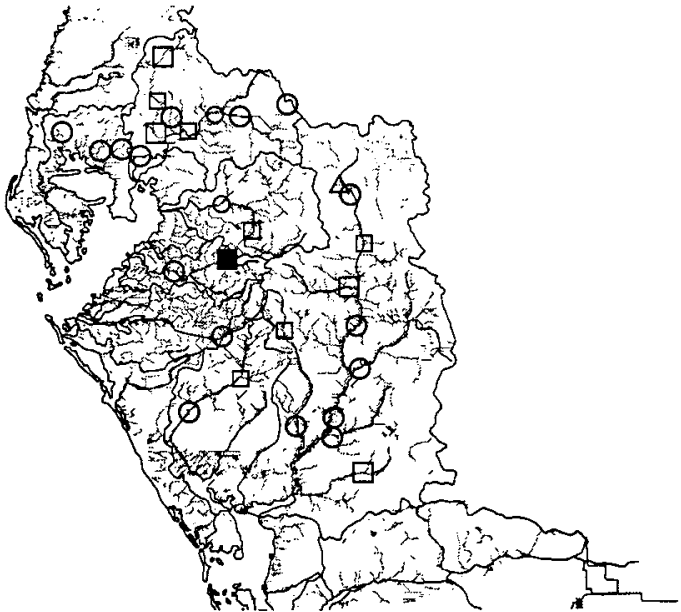

B. La Niña Winter

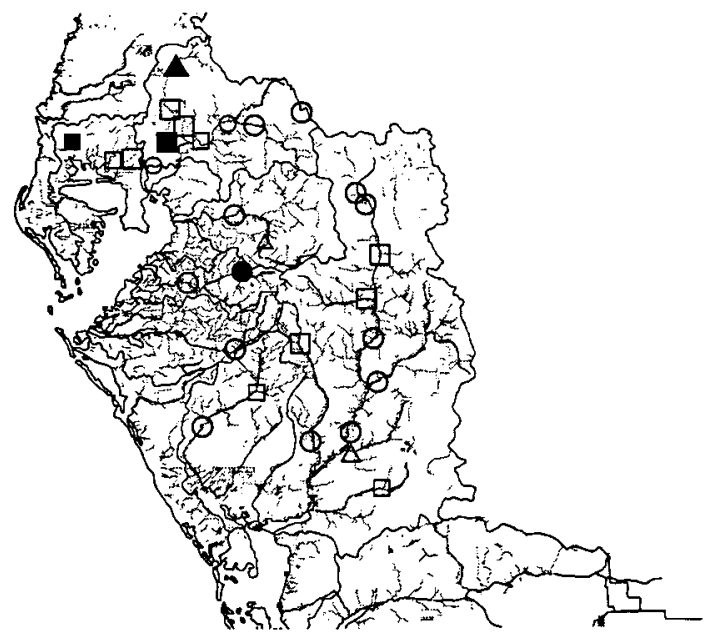

D. La Niña Spring

\section{Significance Level}

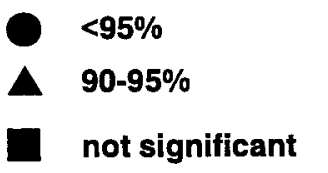

FIG. 4. (a)-(h) Seasonal ENSO maps of mean river flow in south-central Florida, showing the significance level for each stations for the approximate randomized difference of means test and the percent deviation from mean neutral season river flow.

\section{Summary and conclusions}

We have examined seasonal precipitation in Florida and river discharge in south-central Florida and have analyzed their spatial and temporal relationships with extreme phases of ENSO. Our results are in broad agree- ment with those obtained in previous studies that have included Florida. However, we provide a more detailed description of these relationships regarding their spatial characteristics and temporal development. Also, we have used datasets and methods that are easily replicable 


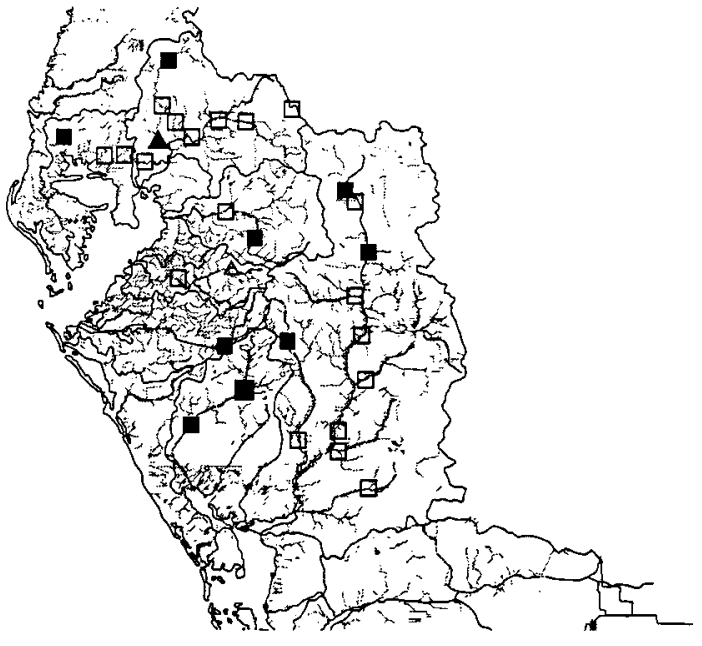

E. El Niño Summer

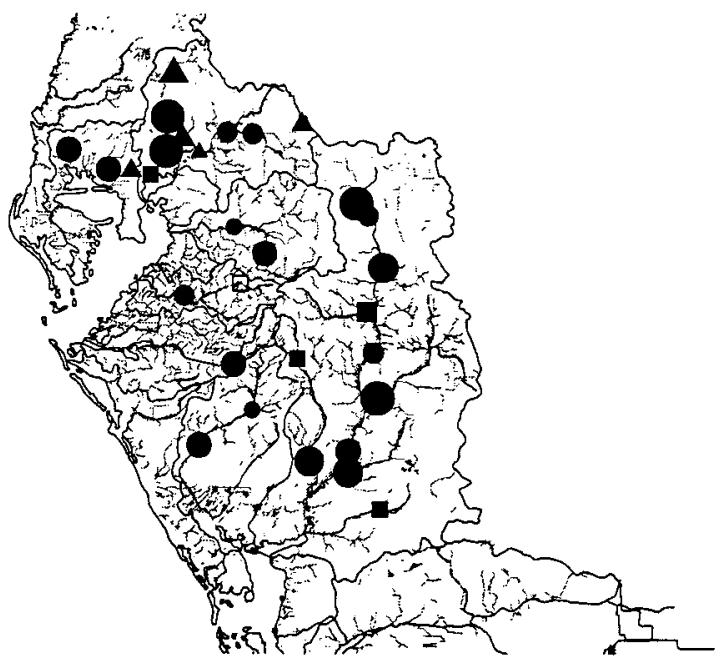

G. El Niño Fall

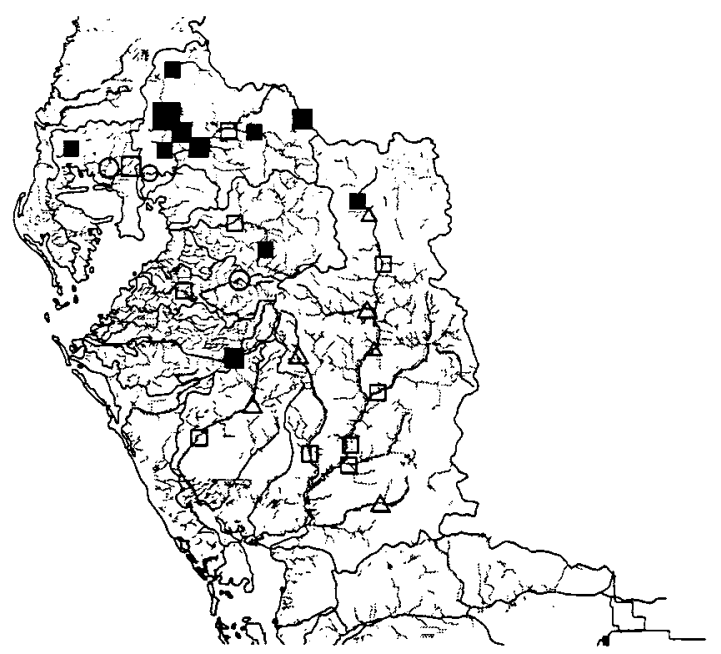

F. La Niña Summer

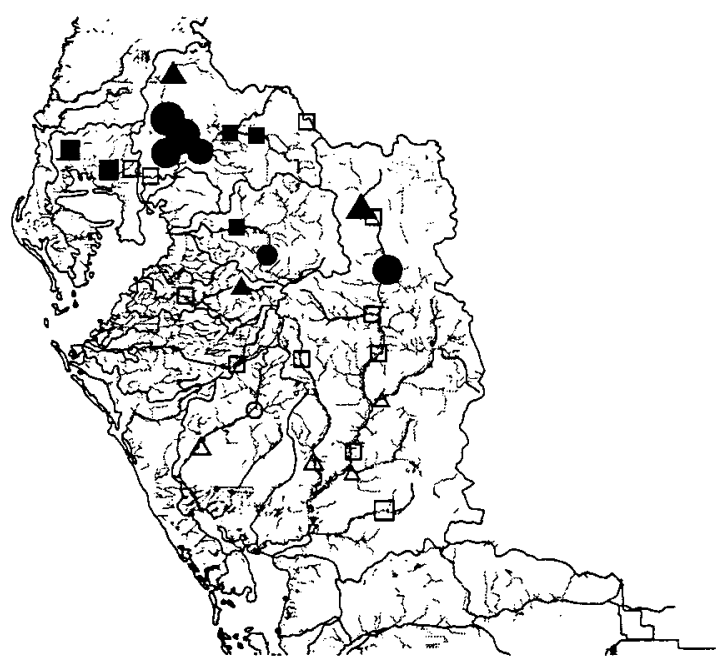

H. La Niña Fall

\section{\% Deviation from Neutral Flow}

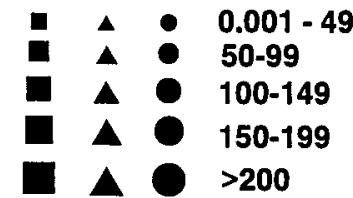

FIG. 4. (Continued)

\section{Significance Level}

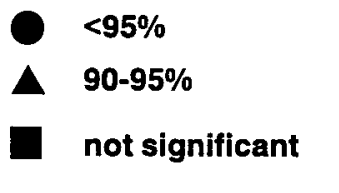

by regional and local planners responsible for assessing local impacts of climate variability on water resources, agriculture, tourism, and other economically and societally important topics. We suggest that the interannual variability in the tropical Pacific Ocean, as manifested by monthly Niño-3.4 sea surface temperature anomalies, is an important contributor to the seasonal variability of precipitation and river discharge in Florida at interannual scales. Our results suggest that Florida does not respond as a uniform region, particularly with respect to precipitation in the Panhandle and the southernmost areas of Florida. Seasonal river discharge in south-cen- 
tral Florida responds in a complicated manner to ENSO conditions; however, we have documented significant seasonal ENSO patterns.

Acknowledgments. We would like to acknowledge the following institutions for their support of this research: U.S. Environmental Protection Agency (EPA), NOAA Office of Global Programs, and the National Weather Service Tampa Bay Office. In addition, we would like to thank Dr. James O'Brien and Dr. Robert Livezey as well as the anonymous reviewers for their thoughtful suggestions.

\section{REFERENCES}

Albright, M., 1998: El Niño came to town and kept tourists away. St. Petersburg Times, 9 April, p. E1

Barbé, D. E., and J. C. Francis, 1995: An analysis of seasonal fecal coliform levels in the Tchefuncte River. Water Resour. Bull., 31, $141-146$

Bove, M. C., J. B. Elsner, C. W. Landsea, X. Niu, and J. J. O'Brien, 1998: Effect of El Niño on U.S. landfalling hurricanes, revisited. Bull. Amer. Meteor. Soc., 79, 2477-2482.

Brown, B. G., R. W. Katz, and A. H. Murphy, 1986: On the economic value of seasonal-precipitation forecasts: The fallowing/planting problem. Bull. Amer. Meteor. Soc., 67, 833-841.

Checkley, W., L. D. Epstein, R. H. Gilman, D. Figueroa, R. I. Cama, J. A. Patz, and R. E. Black, 2000: Effects of El Niño and ambient temperature on hospital admissions for diarrhoeal diseases in Peruvian children. Lancet, 335, 442-450.

Climate Prediction Center, cited 2000: El Niño-Southern Oscillation, and its associated links. [Available online at http://www.cpc.ncep. noaa.gov/products/.]

Compagnucci, R. H., and W. M. Vargas, 1998: Inter-annual variability of the Cuyo Rivers' streamflow in the Argentinean Andean Mountains and ENSO events. Int. J. Climatol., 18, 1593-1609.

Depetris, P. J., S. Kempe, M. Latif, and W. G. Mook, 1996: ENSOcontrolled flooding in the Paraná River (1904-1991). Naturwissenschaften, 83, 127-129.

Environmental Protection Agency, 1999: Action Plan for Beaches and Recreational Waters. EPA Rep. EPA/600/R-98/079, Washington, DC, $19 \mathrm{pp}$. [Available from Environmental Protection Agency, 1200 Pennsylvania Avenue, NW, Washington, DC 20460.]

Epstein, P. R., 1998: Watching El Niño. Public Health Rep., 113, 331-332.

Ferguson, C. M., B. G. Coote, N. J. Ashbolt, and I. M. Stevenson, 1996: Relationships between indicators, pathogens and water quality in an estuarine system. Water Res., 30, 2045-2054.

Flannery, M. S., H. C. Downing Jr., G. A. McGarry, and M. O. Walters, 1992: Increased nutrient loading and baseflow supplementation in the Little Manatee River watershed. Proc. Tampa Bay Area Scientific Information Symp. (BASIS) 2, Tampa, FL, 369-395. [Available from Tampa Bay Regional Planning Council, 9455 Koger Blvd., St. Petersburg, FL 33702.]

Gershunov, A., and T. P. Barnett, 1998: ENSO influence on intraseasonal extreme rainfall and temperature frequencies in the contiguous United States: Observations and model results. J. Climate, 11, 1575-1586.

Goyal, S. M., C. P. Gerba, and J. L. Melnick, 1978: Prevalence of human enteric viruses in coastal canal communities. J. Water Pollut. Control Fed., 50, 2247-2257.

Gray, W. M., 1984: Atlantic seasonal hurricane frequency. Part II: Forecasting its variability. Mon. Wea. Rev., 112, 1669-1683.

Hansen, J. W., A. W. Hodges, and J. W. Jones, 1998: ENSO influences on agriculture in the southeastern United States. J. Climate, 11, 404-411.

, J. W. Jones, C. F. Kiker, and A. W. Hodges, 1999: El Niño-
Southern Oscillation impacts on winter vegetable production in Florida. J. Climate, 12, 92-102.

Hanson, K., and G. A. Maul, 1991: Florida precipitation and the Pacific El Niño, 1895-1989. Florida Sci., 54, 160-68.

Hoerling, M. P., A. Kumar, and M. Zhong, 1997: El Niño, La Niña, and the nonlinearity of their teleconnections. J. Climate, 10, $1769-1786$

Kahya, E., and J. A. Dracup, 1993: U.S. streamflow patterns in relation to the El Niño/Southern Oscillation. Water Resour. Res., 29, 2491-2503.

Kiladis, G. N., and H. F. Diaz, 1989: Global climatic anomalies associated with extremes in the Southern Oscillation. J. Climate, 2, 1069-1090.

Livezey, R. E., and T. M. Smith, 1999: Covariability of aspects of North American climate with global sea surface temperatures on interannual to interdecadal timescales. J. Climate, 12, 289-302.

_- M. Masutani, A. Leetmaa, H. Rui, M. Ji, and A. Kumar, 1997: Teleconnective response of the Pacific-North American region atmosphere to large central equatorial Pacific SST anomalies. $J$. Climate, 10, 1787-1820.

McCabe, G. J., and M. D. Dettinger, 1999: Decadal variations in the strength of ENSO teleconnections with precipitation in the western United States. Int. J. Climatol., 19, 1399-1410.

Montroy, D. L., M. B. Richman, and P. J. Lamb, 1998: Observed nonlinearities of monthly teleconnections between tropical Pacific sea surface temperature anomalies and central and eastern North American precipitation. J. Climate, 11, 1218-1835.

National Center for Atmospheric Research, 1994: Report to the nation: On our changing planet. Report pursuant to NOAA Award \#NA27GP0232-01, Spring/\#3, 23 pp.

National Oceanic and Atmospheric Administration, cited 2000: Population: Distribution, density and growth. NOAA's State of the Coast Report 1998. [Available online at http://state_of_coast.noaa.gov/ bulletins/html/pop_01/pop.html.]

Noreen, E. W., 1989: Computer-Intensive Methods for Testing Hypotheses. John Wiley and Sons, $229 \mathrm{pp}$.

Piechota, T. C., and J. A. Dracup, 1999: Long-range forecasting using El Niño-Southern Oscillation indicators. J. Hydrol. Eng., 4, 144-151.

Ropelewski, C. F., and M. S. Halpert, 1986: North American precipitation and temperature patterns associated with the El Niño Southern Oscillation (ENSO). Mon. Wea. Rev., 114, 2352-2362. , and - 1989: Precipitation patterns associated with the high index phase of the Southern Oscillation. J. Climate, 2, 268-284.

— relationships. J. Climate, 9, 1043-1059.

Sittel, M. C., 1994a: Marginal probabilities of the extremes of ENSO events for temperature and precipitation in the southeastern United States. Tech. Rep. 94-1, Center for Ocean-Atmospheric Studies, The Florida State University, Tallahassee, FL, 155 pp. [Available from Center for Ocean-Atmosphere Prediction Studies, The Florida State University, Tallahassee, FL 32306.]

_ 1994b: Differences in the means of ENSO extremes for maximum temperature and precipitation in the United States. Tech. Rep. 94-2, Center for Ocean-Atmospheric Studies, The Florida State University, Tallahassee, FL, 50 pp. [Available from Center for Ocean-Atmosphere Prediction Studies, The Florida State University, Tallahassee, FL 32306.]

Southwest Florida Water Management District, 1998: Comprehensive Watershed Management Plan, Tampa Bay/Anclote River. Vol. I. Assessment. Draft. [Available from SWFWMD, 7601 U.S. Highway $301 \mathrm{~N}$, Tampa, FL 33638.]

Sun, H., and D. J. Furbish, 1997: Annual precipitation and river discharges in Florida in response to El Niño- and La Niña-sea surface temperature anomalies. J. Hydrol., 199, 74-87.

Wyer, M. D., D. Kay, G. F. Jackson, H. M. Dawson, J. Yeo, and L. Tanguy, 1995: Indicator organism sources and coastal water quality: A catchment study on the Isle of Jersey. J. Appl. Bacteriol., 78, 290-296.

Zorn, M. R., and P. R. Waylen, 1997: Seasonal response of mean monthly streamflow to El Niño/southern oscillation in north central Florida. Prof. Geogr., 49, 51-62. 